\title{
Ethics in medicine: a White Paper by the IAAT
}

\author{
Dr. Carolina Diamandis ${ }^{1}$ and The IAAT Ethics in Medicine Working Group ${ }^{1}$
}

${ }^{1}$ Affiliation not available

June 9, 2021

\begin{abstract}
Medicine has always reflected the behavior of its practitioners. It can look back on an impressive history with the Hippocratic Oath, which is approximately 2000 to 2500 years old. But despite this history, the question remains why there should be medical ethics or whether it is not sufficient to demand morally of a physician what is to be demanded of every citizen anyway.

A paper by the "Ethics in Medicine Working Group" of the International Association of Therapists \& Medical Doctors (IAAT).
\end{abstract}

\section{Hosted file}

Medical Ethics IAAT.pdf available at https://authorea.com/users/410930/articles/525435ethics-in-medicine-a-white-paper-by-the-iaat 